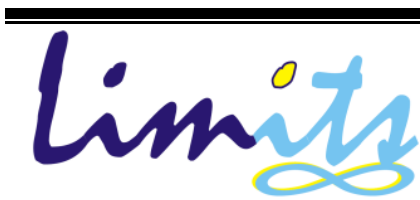

Journal of Mathematics and Its Applications

E-ISSN: 2579-8936

P-ISSN: 1829-605X

Vol. 16, No. 1, Agustus 2019, 27-38

\title{
Penentuan Open/Closed Fasilitas Tempat Pembuangan Sampah dengan Mempertimbangkan Desain Fasilitas dan Sarana Pendidikan Formal
}

\author{
Cahaya Anniss aa' Fathonah ${ }^{1}$ *, Utaminingsih Linarti ${ }^{2}$ \\ ${ }^{1,2}$ Universitas Ahmad Dahlan Yogyakarta; Jl. Prof. Dr. Soepomo, Janturan, Warungboto, Yogyakarta \\ ${ }^{1,2}$ Laboratorium Optimasi dan Simulasi, Program Studi Teknik Industri, Fakultas Teknologi Industri \\ e-mail: cahaya1400019126@webmail.uad.ac.id
}

\begin{abstract}
Abstrak
Adanya aduan dari masyarakat maupun dari walikota Kota Yogyakarta mengenai keberadaan Tempat Pembuangan Sementara (TPS) yang dianggap memberikan dampak buruk bagi lingkungan. Selain itu, beberapa lokasi TPS menyebabkan kemacetan saat pengambilan sampah untuk dibawa ke Tempat Pembuangan Akhir (TPA). Menurut data dari DLH Kota Yogyakarta 32,7\% Tempat Pembuangan Sementara (TPS) berada di Sektor Krasak. TPS di sektor krasak lebih didominasi Tempat Pembuangan Sementara berukuran kecil. Kapasitas TPS yang tersedia di sektor Krasak lebih besar dibandingkan volume sumber sampah. Ketidakseimbangan tersebut dapat dipenuhi dengan melakukan penutupan TPS yang berukuran kecil. Selain itu terdapat TPS yang tidak dapat menampung sumber sampah dengan jarak terdekat, sehingga perlu dilakukan perluasan fasilitas (redesign). Fasilitas umum berupa pendidikan formal dapat memberikan tambahan penyumbang timbulan sampah. Penelitian ini mencoba untuk meminimalkan jumlah TPS di Sektor Krasak dengan mempertimbangkan kapasitas penampungan TPS. Pendekatan penyelesaikan permasalahan ini menggunakan set covering problem. Penentuan fasilitas yang diperluas dilakukan secara diskrit. Keputusan terbaik menggunakan tiga kondisi yaitu: (1) Peningkatan kapasitas TPSS Tribrata, (2) Peningkatkan kapasitas TPSS Kusbini I dan (3) Peningkatan kapasitas keduanya. Berdasarkan ketiga kondisi tersebut terpilih keputusan terbaik merupakan kondisi 2, dimana peningkatkan TPSS Kusbini I sesuai kapasitas maksimal untuk TPSS sebesar $32 \mathrm{~m}^{3}$ dari lima kelurahan di Kecamatan Gondokusuman dan keseluruhan sarana pendidikan formal memerlukan total kapasitas TPS total sebesar $118 \mathrm{~m}^{3}$. Sehingga, TPS yang akan tetap dibuka yaitu Depo Sagan, Landasan Kontainer RRI, TPSS Pengok dan TPSS Kusbini I.
\end{abstract}

Kata Kunci: set covering problem, design fasilitas, tempat pembuangan sementara 


\begin{abstract}
There was a complaint from the community and the mayor of the city of Yogyakarta regarding the existence of a Temporary Disposal Site (TPS) which was considered to have a negative impact on the environment. In addition, several TPS locations caused congestion when collecting garbage to be taken to the Final Disposal Site According to data from the City of Yogyakarta DLH 32.7\% of Temporary Disposal Sites (TPS) are in the Krasak Sector. TPS in the secondary sector is dominated by small-sized Temporary Disposal Sites. The capacity of TPS available in the Krasak sector is greater than the volume of garbage sources. This imbalance can be fulfilled by closing small sized polling stations. In addition there are polling stations that cannot accommodate the nearest source of garbage, so that facilities need to be expanded. Public facilities in the form of formal education can provide additional contributors to waste generation. This study attempts to minimize the number of polling stations in the Krasak Sector by considering the TPS holding capacity. This problem solving approach uses the set covering problem. Determination of expanded facilities is carried out discretely. The best decisions use three conditions, namely: (1) Increasing the capacity of TPSS Tribrata, (2) Increasing the capacity of TPSS Kusbini I and (3) Increasing the capacity of both. Based on the three conditions selected the best decision is condition 2, where increasing TPSS Kusbini I according to the maximum capacity for TPSS of $32 \mathrm{~m}^{3}$ from five kelurahan in Gondokusuman District and the overall formal education facilities requires a total total TPS capacity of $118 \mathrm{~m}^{3}$. So, the TPS that will remain open are Depo Sagan, RRI Container Base, TPSS Pengok and TPSS Kusbini I.
\end{abstract}

Keywords: set covering problem, design facility, temporary landfill (tempat pembuangan sampah)

\title{
1 Pendahuluan
}

Dinas Lingkungan Hidup (DLH) Kota Yogyakarta sering mendapat aduan dari mas yarakat tentang keberadaan TPS yang dirasa mencemari lingkungan dan menyebabkan kemacetan saat pengambilan sampah untuk dibawa menuju Tempat Pembuangan Akhir (TPA). Aduan tersebut tidak hanya berasal dari masyarakat tetapi juga berasal dari Walikota Kota Yogyakarta. Menurut data dari DLH Kota Yogyakarta, 32,7\% Tempat Pembuangan Sementara (TPS) berada di Sektor Krasak. TPS terdiri dari tiga bentuk yaitu: (1) tempat pembuangan sampah sementara (TPSS), (2) Landasan Kontainer dan (3) Depo. Sektor Krasak didominasi TPSS berukuran kecil. Sumber sampah berasal dari masyarakat yang bertempat tinggal di kecamatan. Selain itu, sumber sampah juga didominasi dari fasilitas publik yang ada di lingkungan tersebut. Fasilitas publik yang mendominasi adalah sarana pendidikan formal karena mendominasi dengan jumlah 70 sarana pendidikan formal berupa sekolah dan universitas. Ketidakseimbangan antara jumlah TPS dan sumber sampah juga terjadi pada sektor ini, jumlah TPS jauh lebih banyak dibandingkan dengan jumlah sumber sampah. Berdasarkan data total volume TPS sebanyak $118 \mathrm{~m}^{3}$ sedangkan total volume sumber sampah masyarakat sebanyak $98,90 \mathrm{~m}^{3}$ dan volume sumber sampah sekolah maupun universitas sebanyak 11,6 $\mathrm{m}^{3}$. Ketidakseimbangan tersebut diakibatkan banyaknya jumlah TPSS yang memiliki volume yang kecil yaitu $1 \mathrm{~m}^{3}$. Di sisi lain, terdapat beberapa TPS yang tidak dapat menampung sampah dari jarak terdekat minimum dari sumber sampah yang 
ada. Sehingga terdapat beberapa TPS yang sampahnya berada di luar TPS. Hal tersebut mengakibatkan adanya perluasan ukuran TPS dengan melakukan redesign ukuran TPS maupun penambahan fasilitas baru. Redesign ukuran TPS yang dimaksudkan adalah perluasan ukuran TPS.

Penelitian ini bertujuan mengakomodasi rencana DLH Kota Yogyakarta untuk mengurangi TPSS berukuran kecil dan memaksimalkan kapasitas TPS berukuran besar [1]. Terdapat beberapa model untuk menentukan lokasi fasilitas TPS yang layak beserta efektifitas dan efisiensinya. Model penyelesaian permasalahan tersebut menggunakan model set covering problem. Penelitian menggunakan set covering problem untuk menyelesaikan permasalahan nyata telah banyak dikembangkan. Penggunaan set covering model untuk menentukan jumlah minimum yang optimal fasilitas stasiun kebakaran untuk usulan pemerintah Kota Changlun dengan batasan coverage waktu [2]. Penyelesaian permasalahan penentuan lokasi dan jumlah pemberhentian halte trem Kota Surabaya dengan adanya kriteria lokasi pemberhentian trem [3]. Set covering problem yang diasumsikan sebagai discrete location model yaitu model yang tidak membuat asumsi tertentu tentang permintaan dan fasilitas lokasi, ketentuan diskrit model terletak pada penentuan koordinat titik permintaan dan kandidat lokasi sudah ditetapkan. Sedangkan jarak antara permintaan dan kandidat lokasi tidak memiliki persyaratan tertentu. Penyelesaian masalah dengan pendekatan set covering problem bertujuan untuk memberikan akses yang layak bagi masyarakat yang akan membuang sampah ke TPS terdekat dengan jumlah TPS yang minimum sesuai apa yang direncanakan oleh DLH Kota Yogyakarta.

\section{Metode Penelitian}

Penelitian ini dilakukan di Tempat Pembuangan Sementara (TPS) sektor Krasak, Yogyakarta dengan mengikuti langkah-langkah yang dapat dibagi menjadi beberapa tahapan yaitu: (1) Screening lokasi untuk menentukan TPS existing yang dapat dilakukan redesign terkait ukuran TPS yang mungkin sesuai dengan kondisi riil yang ada dan (2) Penentuan TPS existing yang ditutup ataupun yang dibuka dan TPS existing yang diperluas. Model matematika merupakan Integer Non Linier Programming (INLP) dan mengacu pada pengembangan model set covering yang dilakukan [4]. Pengembangan model dilakukan dengan menambahkan batasan jarak terdekat dari titik lokasi fasilitas ke titik lokasi masyarakat, terdapat $n$ tipe fasilitas, dan titik lokasi bersifat diskrit. Titik lokasi fasilitas dan luas fasilitas yang akan dibuka ditentukan secara diskrit melalui proses screening location. Pencarian solusi untuk integer programming menggunakan algoritma Branch and Bound dimana terdapat variabel keputusan lokasi fasilitas yang dibuka maupun ditutup merupakan variabel biner [0,1] sehingga diperlukan metode 
penyelesaian dalam ruang solusi secara sistematis. Metode ini pertama kali dikembangkan oleh Lan dan Doig (1960), kemudian dikembangkan Dakin (1965). Prosedur dalam algoritma Branch and Bound yaitu menyelesaikan problema sebagai model kontinyu dimana has il yang diperoleh merupakan mutually exclusive [5]. Solusi model matematika menggunakan bantuan software LINGO 11.0.

Data yang diperlukan adalah data titik lokasi sumber masyarakat, titik lokasi fasilitas sarana pendidikan, titik lokasi TPSS, titik lokasi landasan kontainer, titik lokasi depo, kapasitas masing-masing fasilitas TPS (TPSS, Landasan Kontainer dan Depo), volume sampah sumber masyarakat, volume sampah fasilitas sarana pendidikan, jarak antara titik lokasi sumber masyarakat dengan titik lokasi TPS, jarak antara titik lokasi sarana pendidikan formal dengan titik lokasi fasilitas TPS, jarak maksimum pembuangan sampah dari titik lokasi sumber sampah ke titik lokasi fasilitas, lokasi TPS yang bisa diperluas.

\section{Pengumpulan dan Pengolahan Data}

Pengukuran jarak antara titik lokasi sumber masyarakat maupun fasilitas pendidikan formal ke titik lokasi fasilitas TPS menggunakan perhitungan posisi latitude dan longitude. Data titik lokasi sumber sampah yang berasal dari masyarakat menggunakan asumsi titik berat pada lokasi area. Pada permasalahan penentuan lokasi TPS yang akan dibuka dan ditutup pada sektor krasak ini. Titik lokasi sumber sampah masyarakat diwakilkan pada area kelurahan yang ada di wilayah Krasak sebanyak 5 kelurahan, yaitu kelurahan Kotabaru, kelurahan Baciro, kelurahan Demangan, kelurahan Terban dan kelurahan Klitren. Jumlah titik lokasi sumber sampah sarana pendidikan formal sebanyak 45 terdiri dari jenjang pendidikan sekolah dasar hingga universitas. Sedangkan jumlah titik lokasi fasilitas TPSS sebanyak 21 buah, yaitu TPSS Jl. Herman Yohanes, TPSS Sagan, TPSS Jl. Wardani, TPSS Jl. Wahidin, TPSS Jl. Atmosukarto, TPSS J1. Krasak, TPSS Jl. Kusbini I, TPSS Jl. Kusbini II, TPSS Jl. Ungaran, TPSS J1. I Nyoman Oka, TPSS Jl. Patimura, TPSS J1. Johar Nurhadi, TPSS Jl. Hadi Darsono, TPSS J1. Urip Sumoharjo, TPSS J1. Munggur, TPSS Belakang Duta, TPSS SD Klitren, TPSS Pengok, TPSS Kowilhan, TPSS J1. A Jajuli, dan TPSS Tribrata. Titik lokasi fasilitas Landasan Kontainer, yaitu Kontainer RRI Jogja sebanyak 1 buah dan titik lokasi fasilitas Depo sebanyak 1 buah, yaitu Depo Sagan.

Data titik lokasi sumber sampah yang berasal dari masyarakat menggunakan data yang telah diambil pada penelitian [6]. Sedangkan titik lokasi sarana pendidikan formal dan titik lokasi fasilitas TPS (TPSS, Landasan Kontainer dan Depo) dilakukan dengan bantuan alat GPS 
Garmin e-Trex 10 dan software Google Earth. Jarak maksimum yang diperbolehkan dari titik lokasi sumber masyarakat ke titik lokasi TPS adalah $1000 \mathrm{~m}$.

Model set covering problem yang digunakan untuk menetukan lokasi fasilitas yang akan ditutup atau tetap dibuka dan diperluas menggunakan model acuan [4] berdasarkan pengembangan model set covering problem [7], yang sebelumnya menggunakan model dasar dari [8]. Model matematis penelitian ini bertujuan untuk mengurangi jumlah TPS yang dianggap mengganggu fasilitas publik dan memperluas ukuran TPS (redesign).

Berdasarkan hasil wawancara dengan Kepala Seksi Penanganan Sampah DLH Kota Yogyakarta, pembuangan sampah di sektor Krasak akan dipusatkan kepada Landasan Kontainer RRI Yogyakarta, Depo Sagan dan TPSS dengan lokasi yang mampu diperluas tetapi diluar kelurahan Kotabaru karena padat penduduk. Setelah dilakukan pengamatan awal terdapat TPSS Tribrata dengan ukuran kapasitas $3 \mathrm{~m}^{3}$ di lahan yang masih memungkinkan diperbesar kapasitasnya karena masih terdapat lahan yang mencukupi dan volume bangunan TPSS masih mencukupi untuk menampung lebih dari kapasitas terangkut sekarang.

\section{Notasi Model}

Model matematik pada penelitian ini menggunakan notasi sebagai berikut:

\section{Himpunan:}

$I \quad=$ titik sumber sampah dari masyarakat dengan indeks $i$

$J \quad=$ titik sumber sampah dari sarana pendidikan formal dengan indeks $j$

$K=$ titik alternatif lokasi TPS berbentuk depo dengan indeks $k$

$L=$ titik alternatif lokasi TPS berbentuk kontainer dengan indeks $l$

$M \quad=$ titik alternatif lokasi TPS berbentuk TPSS dengan indeks $m$

$C_{k}=$ kapasitas lokasi Depo dengan indeks $k\left(\mathrm{~m}^{3} / \mathrm{hari}\right)$

$C_{l}=$ kapasitas lokasi Landasan Container dengan indeks $l\left(\mathrm{~m}^{3} / \mathrm{hari}\right)$

$\mathrm{Cm}=$ kapasitas lokasi TPSS dengan individu $\left(\mathrm{m}^{3} /\right.$ hari $)$

$\mathrm{V} i=$ volume produksi sumber sampah dari masyarakat dengan indeks $i\left(\mathrm{~m}^{3} / \mathrm{hari}\right)$ 
$\mathrm{V} j \quad=$ volume produksi sumber sampah dari sarana pendidikan formal dengan indeks $j\left(\mathrm{~m}^{3} / \mathrm{hari}\right)$

$d_{\max }=$ jarak maksimal antara pembuang sampah dengan fasilitas pembuangan dengan melihat kemampuan orang berjalan kaki dengan membawa beban

$d_{i k}=$ jarak tempuh antara titik sumber sampah dengan indeks $i$ dengan alternatif lokasi TPS dengan indeks $k$

$d_{i j} \quad=$ jarak tempuh antara titik sumber sampah dengan indeks $i$ dengan alternatif lokasi TPS dengan indeks $l$

$d_{i m}=$ jarak tempuh antara titik sumber sampah dengan indeks $i$ dengan alternatif lokasi TPS dengan indeks $m$

$d_{j k} \quad=$ jarak tempuh antara titik sumber sampah dengan indeks $\mathrm{j}$ dengan alternatif lokasi TPS dengan indeks $k$

$d_{j l} \quad=$ jarak tempuh antara titik sumber sampah dengan indeks $j$ dengan alternatif lokasi TPS dengan indeks $l$

$d_{j m}=$ jarak tempuh antara titik sumber sampah dengan indeks $j$ dengan alternatif lokasi TPS dengan indeks $m$

$T_{d} \quad=$ total jarak tempuh sebagai jarak pemenuhan

$N_{i j} \quad=\left\{k, l, m \mid d_{i k}+d_{i l}+d_{i m}+d_{j k}+d_{j l}+d_{j m} \leq T_{d}\right\}=$ semua alternatif lokasi TPS yang meliputi titik sumber sampah dengan indeks $i$ dan $j$

\section{Variabel keputusan:}

$X_{k} \quad=1$, jika depo $k$ menjadi lokasi penempatan sumber sampah dan 0 , jika depo $k$ tidak menjadi lokasi penempatan sumber sampah

$X_{l} \quad=1$, jika kontainer $l$ menjadi lokasi penempatan sumber sampah dan 0 , jika depo $l$ tidak menjadi lokasi penempatan sumber sampah

$X_{m} \quad=1$, jika TPSS $m$ menjadi lokasi penempatan sumber sampah dan 0, jika TPSS $m$ tidak menjadi lokasi/ penempatan sumber sampah 
$Y_{i k}=1$, jika sumber sampah $i$ dapat dipenuhi oleh alternatif lokasi $k$ dan 0 , jika sumber sampah $i$ tidak dapat dipenuhi oleh alternatif $k$

$Y_{i l} \quad=1$, jika sumber sampah $i$ dapat dipenuhi oleh alternatif lokasi $l$ dan 0 , jika sumber sampah $i$ tidak dapat dipenuhi oleh alternatif $l$

$Y_{\text {im }}=1$, jika sumber sampah $i$ dapat dipenuhi olehm alternatif lokasi $m$ dan 0 , jika sumber sampah $i$ tidak dapat dipenuhi oleh alternatif $m$

$Y_{j k}=1$, jika sumber sampah $j$ dapat dipenuhi oleh alternatif lokasi $k$ dan 0 , jika sumber sampah $j$ tidak dapat dipenuhi oleh alternatif $k$

$Y_{j l} \quad=1$, jika sumber sampah $j$ dapat dipenuhi oleh alternatif lokasi $l$ dan 0 , jika sumber sampah $j$ tidak dapat dipenuhi oleh alternatif $l$

$Y_{j m}=1$, jika sumber sampah $j$ dapat dipenuhi oleh alternatif lokasi $m$ dan 0 , jika sumber sampah $j$ tidak dapat dipenuhi oleh alternatif $m$

Formulasi model set covering yang telah dikembangkan [4] dijelaskan sebagai berikut:

\section{Fungsi Tujuan}

Tujuan dalam penelitian ini adalah meminimalkan jumlah TPS yang terdiri dari tiga jenis yaitu depo, landasan kontainer dan TPSS. Minimasi mempertimbangkan kapasitas dari TPS.

$$
\text { Minimize } \sum_{k \in K} C_{k} X_{k}+\sum_{l \in L} C_{l} X_{l}+\sum_{m \in M} C_{m} X_{m}
$$

\section{Batasan}

a. Jumlah Sampah yang dapat Terlayani

Setiap sumber sampah yang terdiri dari masyarakat dan sarana pendidikan formal. Sumber sampah setidaknya dapat terlayani oleh satu fasilitas TPS.

$$
\begin{array}{ll}
\sum_{k, l, m \in N_{i}} Y_{i k}+Y_{i l}+Y_{i m} \geq 1 & \forall i \in I \\
\sum_{k, l, m \in N_{j}} Y_{j k}+Y_{j l}+Y_{j m} \geq 1 & \forall j \in J
\end{array}
$$

b. Kapasitas TPS

TPS memiliki kapasitas dalam menampung buangan sampah dari sumber sampah masyarakat maupun dari sarana pendidikan formal.

$$
\sum_{i \in I} V_{i} Y_{i k}+\sum_{j \in J} V_{j} Y_{j k} \leq C_{k} X_{k} \forall k \in K
$$




$$
\begin{aligned}
& \sum_{i \in I} V_{i} Y_{i l}+\sum_{j \in J} V_{j} Y_{j l} \leq C_{l} X_{l} \quad \forall l \in L \\
& \sum_{i \in I} V_{i} Y_{i m}+\sum_{j \in J} V_{j} Y_{j m} \leq C_{m} X_{m} \quad \forall m \in M
\end{aligned}
$$

c. Jarak Pembuangan Maksimal

Jarak maksimal pembuangan yang berasal dari jarak tempuh maksimal seorang pejalan kaki yang membawa beban sehingga jarak antara sumber sampah dengan fasilitas tidak lebih dari jarak maksimal.

$$
\begin{array}{ll}
d_{\max } X_{k} \geq \max \left\{d_{k}^{i}\right\} Y_{i k} & \forall k \in K \\
d_{\max } X_{l} \geq \max \left\{d_{l}^{i}\right\} Y_{i l} & \forall l \in L \\
d_{\max } X_{m} \geq \max \left\{d_{m}^{i}\right\} Y_{i m} & \forall m \in M \\
d_{\max } X_{k} \geq \max \left\{d_{k}^{j}\right\} Y_{i k} & \forall k \in K \\
d_{\max } X_{l} \geq \max \left\{d_{l}^{j}\right\} Y_{i l} & \forall l \in L \\
d_{\max } X_{m} \geq \max \left\{d_{m}^{j}\right\} Y_{i m} & \forall m \in M
\end{array}
$$

d. Keputusan

$\begin{array}{cc}X_{k}\{0,1\} & \forall k \in K \\ X_{l}\{0,1\} & \forall l \in L \\ X_{m}\{0,1\} & \forall m \in M \\ Y_{i k}\{0,1\} & \forall i \in I \\ Y_{i l}\{0,1\} & \forall i \in I \\ Y_{i m}\{0,1\} & \forall i \in I \\ Y_{j k}\{0,1\} & \forall j \in J \\ Y_{j l}\{0,1\} & \forall j \in J \\ Y_{j m}\{0,1\} & \forall j \in J\end{array}$

TPSS Tribrata merupakan TPS milik pemerintah berukuran $3 \mathrm{~m}^{3}$ yang berdiri diatas lahan pemerintah ataupun hibah masyarakat sekitar sehingga jika akan ditingkatkan kapasitasnya tidak akan mengganggu lingkungan masyarakat. Ukuran tersebut mempertimbangkan dengan luas tanah dan kegiatan penyaluran sampah ke TPA. Selain itu, pada pengamatan awal juga ditemui TPSS di Jalan Kusbini I yang berukuran $9 \mathrm{~m}^{3}$ dapat diperbesar kapasitasnya karena ukuran bangunan masih mencukupi untuk kapasitas lebih dan masih terdapat lahan sehingga dapat 
diperbesar luasannya. Berdasarkan kemampuan peningkatan kapasitas kedua TPSS yang dapat dilakukan tiga kondisi penyelesaian terbaik yaitu, peningkatan kapasitas TPSS Tribrarta, peningkatan kapasitas TPSS Kusbini I, dan peningkatan kapsitas keduanya.

Tiga kondisi yang berbeda ditentukan untuk optimisasi penentuan lokasi fasilitas TPS, yaitu: (1) Kondisi I dengan meningkatkan kapasitas pada TPSS Tribrata dari $3 \mathrm{~m}^{3}$ menjadi 21 $\mathrm{m}^{3}$, (2) Kondisi II meningkatkan kapasitas TPSS Kusbini I dari 9 hingga $32 \mathrm{~m}^{3}$ dan (3) Kondisi III dengan meningkatkan kapasitas keduanya. Pengolahan data rill dengan tiga kondisi menghasilkan perbedaan untuk TPS yang dibuka. Penampungan sementara sumber sampah di TPSS dari ketiga kondisi dapat dilihat pada Tabel 1.

Tabel 1. TPS yang dibuka beserta sumber sampah dari masyarakat maupun fasilitas pendidikan formal

\begin{tabular}{|c|c|c|c|c|c|}
\hline No. & Sumber S ampah & $\begin{array}{l}\text { Volume } \\
\text { Sampah }\end{array}$ & $\begin{array}{l}\text { TPS Penampung } \\
\text { untuk kondisi I }\end{array}$ & $\begin{array}{l}\text { TPS Penampung } \\
\text { untuk kondisi II }\end{array}$ & $\begin{array}{l}\text { TPS Penampung } \\
\text { untuk kondisi III }\end{array}$ \\
\hline 1 & Kotabaru & 6,33 & TPSS Pengok & TPSS Pengok & TPSS Kusbini I \\
\hline 2 & Baciro & 28,57 & Kontainer Rri & Kontainer Rri & Kontainer Rri \\
\hline 3 & Demangan & 20,30 & TPSS Tribrata & TPSS Kusbini I & TPSS Tribrata \\
\hline 4 & Klitren & 22,14 & Depo Sagan & TPSS Pengok & TPSS Kusbini I \\
\hline 5 & Terban & 21,54 & TPSS Pengok & Depo Sagan & Depo Sagan \\
\hline 6 & Akademi Akuntansi YKPN & 0,13 & TPSS Kusbini I & TPSS Kusbini I & TPSS Hadidarsono \\
\hline 7 & $\begin{array}{l}\text { Akademi Keperawatan Bethesda } \\
\text { Yakkum }\end{array}$ & 0,69 & Kontainer Rri & TPSS Kusbini I & TPSS Kusbini I \\
\hline 8 & Akademi Teknik Ykpn & 0,10 & TPSS Kusbini I & TPSS Kusbini I & TPSS Kusbini I \\
\hline 9 & Man Yogy akarta 1 & 0,43 & TPSS Pengok & TPSS Kusbini I & Depo Sagan \\
\hline 10 & Politeknik Lpp & 0,44 & Kontainer Rri & Depo Sagan & TPSS Atmosukarto \\
\hline 11 & SD Kanisius Kotabaru I & 0,05 & Depo Sagan & TPSS Kusbini I & TPSS Hadidarsono \\
\hline 12 & SD Masjid Syuhada & 0,29 & TPSS Kusbini I & TPSS Kusbini I & TPSS Hadidarsono \\
\hline 13 & SD Muhammadiy ah Demangan & 0,21 & TPSS Kusbini I & Depo Sagan & TPSS Tribrata \\
\hline 14 & SD Muhammadiy ah Sagan & 0,23 & TPSS Kusbini I & TPSS Kusbini I & TPSS Hadidarsono \\
\hline 15 & SD Muhammadiy ah Sapen 1 & 0,32 & TPSS Tribrata & TPSS Kusbini I & TPSS Atmosukarto \\
\hline 16 & SD Negeri Bhay angkara & 0,20 & TPSS Kusbini I & Depo Sagan & $\begin{array}{c}\text { Depo Sagan/ TPSS } \\
\text { Hadidarsono }\end{array}$ \\
\hline 17 & SD Negeri Demangan & 0,16 & TPSS Kusbini I & TPSS Kusbini I & Depo Sagan \\
\hline 18 & SD Negeri Klitren & 0,06 & TPSS Kusbini I & TPSS Kusbini I & TPSS Kusbini I \\
\hline 19 & SD Negeri Sagan & 0,04 & TPSS Kusbini I & TPSS Kusbini I & TPSS Tribrata \\
\hline 20 & SD Negeri Serayu & 0,18 & TPSS Kusbini I & TPSS Pengok & TPSS Hadidarsono \\
\hline 21 & SD Negeri Terbansari I & 0,11 & TPSS Kusbini I & TPSS Kusbini I & TPSS Hadidarsono \\
\hline 22 & SD Negeri Ungaran I & 0,32 & TPSS Pengok & TPSS Pengok & Kontainer RRI \\
\hline 23 & SMAN 6 Yogy akarta & 0,31 & TPSS Pengok & TPSS Kusbini I & TPSS Atmosukarto \\
\hline 24 & SM AN 9 Yogy akarta & 0,35 & TPSS Kusbini I & TPSS Kusbini I & $\begin{array}{c}\text { Depo Sagan/TPSS } \\
\text { Kusbini I }\end{array}$ \\
\hline 25 & SMAS Bopkri 1 & 0,22 & TPSS Kusbini I & TPSS Kusbini I & TPSS Atmosukarto \\
\hline 26 & SMAS Bopkri2 & 0,21 & TPSS Kusbini I & Kontainer Rri & TPSS Kusbini I \\
\hline 27 & SMAS Budya Wacana & 0,13 & TPSS Kusbini I & TPSS Kusbini I & TPSS Atmosukarto \\
\hline 28 & SMAS Stella Duce 1 & 0,48 & TPSS Pengok & Kontainer Rri & TPSS Kusbini I \\
\hline 29 & SMKS Bopkri 1 Yogyakarta & 0,15 & TPSS Kusbini I & TPSS Kusbini I & TPSS Atmosukarto \\
\hline 30 & SMKS Perindustrian Yogyakarta & 0,10 & TPSS Kusbini I & TPSS Kusbini I & TPSS Tribrata \\
\hline 31 & SMP Bopkri 3 Yogy akarta & 0,18 & TPSS Pengok & Depo Sagan & TPSS Kusbini I \\
\hline 32 & SMP Budya Wacana & 0,09 & TPSS Kusbini I & TPSS Kusbini I & TPSS Kusbini I \\
\hline 33 & SMP Institut Indonesia Yogy akarta & 0,05 & Depo Sagan & TPSS Kusbini I & TPSS Tribrata \\
\hline 34 & SMP ITt M asjid Syuhada Yogy akarta & 0,13 & TPSS Kusbini I & TPSS Kusbini I & TPSS Kusbini I \\
\hline 35 & SMP Muhammadiy ah 10 Yogy akarta & 0,13 & TPSS Kusbini I & TPSS Kusbini I & TPSS Atmosukarto \\
\hline 36 & SMP Negeri 1 Yogy akarta & 0,49 & Depo Sagan & TPSS Pengok & TPSS Hadidarsono \\
\hline 37 & STMIK Pelita Nusantara & 0,06 & Depo Sagan & TPSS Kusbini I & TPSS Kusbini I \\
\hline
\end{tabular}


Penentuan Open/Closed Fasilitas Tempat Pembuangan Sampah dengan

Mempertimbangkan Desain Fasilitas dan Sarana Pendidikan Formal

\begin{tabular}{|c|l|c|c|c|c|}
\hline No. & \multicolumn{1}{|c|}{ Sumber Sampah } & $\begin{array}{c}\text { Volume } \\
\text { Sampah }\end{array}$ & $\begin{array}{c}\text { TPS Penampung } \\
\text { untuk kondisi I }\end{array}$ & $\begin{array}{c}\text { TPS Penampung } \\
\text { untuk kondisi II }\end{array}$ & $\begin{array}{c}\text { TPS Penampung } \\
\text { untuk kondisi III }\end{array}$ \\
\hline 38 & Universitas Kristen Duta Wacana & 1,08 & TPSS Kusbini I & TPSS Pengok & $\begin{array}{c}\text { Depo Sagan/ TPSS } \\
\text { Atmosukarto }\end{array}$ \\
\hline 39 & SD Juara & 0,21 & TPSS Kusbini I & Depo Sagan & TPSS Atmosukarto \\
\hline 40 & SD Kanisius Baciro Yogy akarta & 0,29 & TPSS Pengok & TPSS Kusbini I & TPSS Kusbini I \\
\hline 41 & SD Kanisius Gayam I & 0,12 & TPSS Kusbini I & TPSS Kusbini I & TPSS Atmosukarto \\
\hline 42 & SD Muhammadiy ah Gendeng & 0,06 & TPSS Kusbini I & TPSS Kusbini I & Depo Sagan \\
\hline 43 & SD Negeri Baciro & 0,32 & TPSS Pengok & TPSS Pengok & TPSS Hadidarsono \\
\hline 44 & SM AS Piri 1 Yogy akarta & 0,13 & TPSS Kusbini I & TPSS Kusbini I & TPSS Hadidarsono \\
\hline 45 & SMKS Piri 1 Yogy akarta & 1,08 & TPSS Kusbini I & TPSS Kusbini I & Kontainer Rri \\
\hline 46 & SMKS Piri 2 Yogy akarta & 0,05 & Depo Sagan & TPSS Kusbini I & Depo Sagan \\
\hline 47 & SMP Piri 1 Yogy akarta & 0,07 & TPSS Tribrata & TPSS Kusbini I & Depo Sagan \\
\hline 48 & Sekolah Tinggi APMD & 0,96 & TPSS Tribrata & TPSS Kusbini I & TPSS Kusbini I \\
\hline
\end{tabular}

\section{Analisis dan Pembahasan}

Berdasarkan hasil pengolahan dan hasil lokasi fasilitas TPS yang harus dibuka berdasarkan wawancara dengan pihak DLH Kota Yogyakarta, Kondisi II terpilih menjadi keputusan terbaik dengan tetap membuka depo Sagan, landasan kontainer RRI, TPSS Pengok dan TPSS Kusbini I dengan total kapasitas $118 \mathrm{~m}^{3}$. TPSS Kusbini I layak ditingkatkan kapasitasnya lebih besar karena memiliki kapasitas bangunan lebih besar dari TPSS Tribrata selain itu tidak terletak dekat dengan pemukiman warga dan jika diperluas masih terdapat lahan yang lebih mencukupi. Analisis kondisi III dengan perluasan dua TPSS terpilih menurut hasil pengamatan awal dan wawancara tidak menjadi solusi terbaik karena DLH Kota Yogyakarta menginginkan untuk menutup TPS berukuran kecil terutama di sekitar Kelurahan Kotabaru tetapi menurut hasil kondisi III TPS Hadidarsono yang terletak di Kotabaru tetap dibuka karena pengaruh jarak pembuangan sampah yang diinginkan masyarakat adalah yang lebih dekat dari lokasi tempat tinggal sebagai sumber sampah. Selain itu, berdasarkan kondisi ke III TPSS Pengok tidak dibuka sehingga tidak sesuai dengan keinginan DLH Kota Yogyakarta dan pimpinan daerah setempat bahwa penampungan sampah sementara diharapkan tetap terdapat di TPSS Pengok terlihat dari kegiatan perbaikan kelayakan TPSS yang dilakukan pada TPSS tersebut.

Analisis sensitivitas dilakukan dengan menaikkan ataupun menurunkan sumber sampah dengan asumsi berdasarkan wawancara dengan pihak pemerintah besarnya perubahan timbulan sampah yang selama ini ada, yaitu sebesar 25\% dan maksimal pembuangan jarak menjadi $750 \mathrm{~m}$. Berdasarkan data yang diperoleh, kenaikan jumlah sumber sampah sebesar $25 \%$ mengakibatkan volume sampah per hari sejumlah 98,90 $\mathrm{m}^{3}$ untuk sumber sampah dari masyarakat dan 11,63 $\mathrm{m}^{3}$ dari sampah sarana pendidikan formal. Hasil perhitungan dengan menurunkan jumlah sumber sampah sebesar $25 \%$ maka jumlah rata-rata per hari sampah sejumlah $74,17 \mathrm{~m}^{3}$ dari masyarakat dan $8,72 \mathrm{~m}^{3}$ dari sarana pendidikan formal. 


\section{Simpulan}

Berdasarkan hasil pengolahan data serta pembahasan diperoleh kesimpulan yaitu (1) Pengembangan model set covering problem dengan menerapkan tiga sekenario yang berbeda, kondisi I dengan meningkatkan kapasitas pada TPSS Tribrata hingga $21 \mathrm{~m}^{3}$. Sedangkan kondisi II meningkatkan kapasitas TPSS Kusbini I hingga $32 \mathrm{~m}^{3}$ dan kondisi III dengan meningkatkan kapasitas keduanya, (2) Kondisi II terpilih menjadi keputusan terbaik dengan tetap membuka depo Sagan, landasan kontainer RRI, TPSS Pengok dan TPSS Kusbini I dengan total kapasitas $118 \mathrm{~m}^{3}$ dan (3) Analisis sensitivitas dengan meninjau apabila terjadi peningkatan ataupun penurunan dari volume sampah yang dihasilkan oleh sumber sampah. Hasil dari analisis sensitivitas ketika terjadi penurunan jumlah volume sampah $25 \%$ tetap memerlukan 4 TPS, dan ketika terjadi penambahan volume sampah $25 \%$ memerlukan perluasan beberapa TPS agar dapat menutup TPS yang berukuran kecil tetapi tetap dapat menampung sementara sampah sebelum dibawa ke TPA Piyungan. Selain itu jarak maksimal juga dilakukan analisis sensitivitas dengan meningkatkat $25 \%$ dan sebaliknya sehingga ditemukan hasil yang berbeda.

Penelitian selanjutnya dapat dikembangkan menggunakan model P-Center selain menggunakan metode set covering problem yang bertujuan untuk mengurangi jumlah fasilitas TPS namun dapat meng-cover demand dari daerah coverage. Proses pengangkutan sampah dari sumber sampah ke TPS dilakukan secara mandiri oleh masyarakat maupun oleh petugas dari tingkat rukun warga, sehingga diperlukan aksesibilitas dalam pengangkutan dengan jarak yang relatif sama, untuk memperoleh prinsip keadilan dengan meminimumkan jarak maksimum. Kemudian dapat dikembangkan pula perluasan asumsi ruang solusi permasalahan dalam penampungan sampah sementara yang masih bersifat diskrit. Penyelesaian permasalahan dapat menggunakan pengembangan model selanjutnya dengan merubah ruang solusi model menjadi network sesuai dengan kondisi riil permasalahan. Sehingga titik permintaan tidak hanya diasumsikan terpusat pada suatu titik.

\section{Daftar Pustaka}

[1] E. A. Rusqiyati, "BLH Yogyakarta mulai kurangi TPS," 2015. [Online]. Available: https://jogja. antaranews.com/berita/329037/blh-yogyakarta-mulai-kurangi-tps. [Accessed: 24-Oct-2018].

[2] N. F. Nik Lah and R. Abd. Rahman, "The Allocation of Fire Stations using Set Cover Approaches," J. Technol. Manag. Bus., vol. 5, no. 3, pp. 8-14, 2018.

[3] A. Ardiansyah and Mardlijah, "Determination of location and numbers of tram stops in 
Surabaya with model set covering problem," Proceeding - ICAMIMIA 2017 Int. Conf. Adv. Mechatronics, Intell. Manuf. Ind. Autom., pp. 337-341, 2018.

[4] C. A. Fathonah, "Pengembangan Model Open/Closed Fasilitas Tempat Pembuangan Sampah dengan Mempertimbangkan Desain dan Sarana Pendidikan Formal," Universitas Ahmad Dahlan, 2018.

[5] A. Iryanto dan G. Tarigan, "Penerapan Metode Branch and Bound Dalam Menentukan Jumlah Produksi Optimum Pada C.V XYZ,” Vol. 2, No. 2, pp. 137-145, 2014.

[6] U. Linarti, "Model Bilevel Programming Penentuan Lokasi dan Level Daya Tarik Fasilitas Dengan Mempertimbangkan Adanya Regulasi Pemerintah dan Saturasi Regional,” Institut Teknologi Bandung, Bandung, 2014.

[7] B. Nugrahadi, "Penerapan Metode Set Covering Problem dalam Penentuan Lokasi dan Alokasi Sampah di Wilayah Kota Surakarta,” Universitas Muhammadiyah Surakarta, 2017.

[8] M. S. Daskin, Network and Discrete Location, Wiley, 1995. 